$$
\begin{aligned}
& \text { SH } \\
& 431 \\
& 042 \mathrm{~s} \\
& 1883
\end{aligned}
$$

0
5

0

0

1

1
5

0 


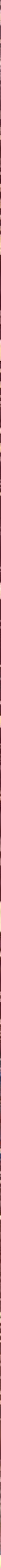


357.

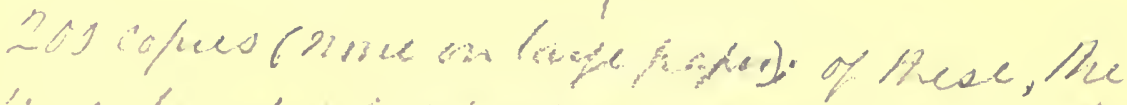

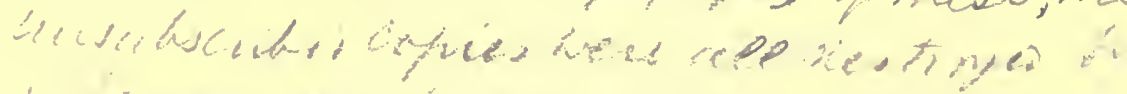

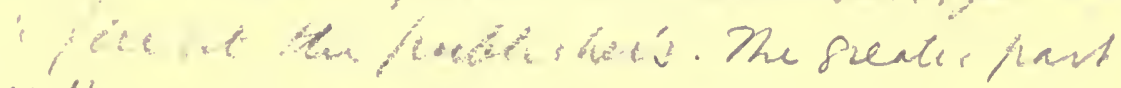
of the imprestion onffeces Mt... fale.

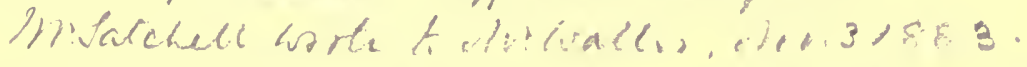

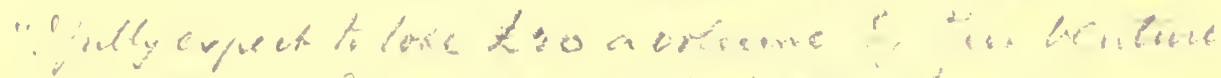

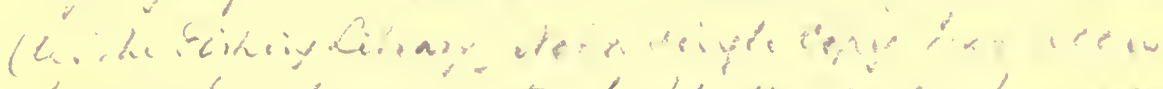

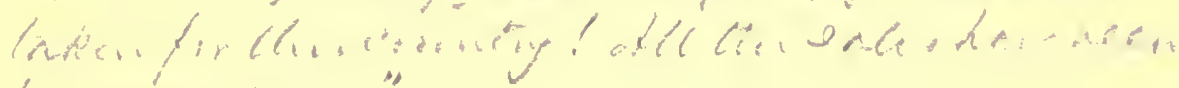
fir centiven." 
Digitized by the Internet Archive in 2007 with funding from Microsoft Corporation 

THE SECRETS OF ANGLING. 1613 

THE

\section{SECRETS OF ANGLING.}

By J[OHN] D[ENNYS] Esqutre:

1613.

A REPRINT, WITH INTRODECTION

BY THOMAS IVESTWOOD.

1.0ND(1) :

II. SATCHELL \& C C..

19, TAVATOCK STREET, COVEXT G.IRIDA. W.

$1 S S ;$. 
6

LONDON:

R. CLAY, SONS, AND TAYLOR,

BREAD STREET HILL. 


\section{SH \\ 5

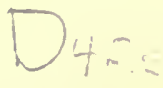

INTRODUCTION.

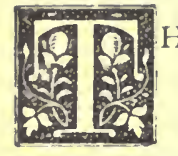

HE English poets of the Art of Angling perplex us neither with their multitude, nor their magnitude. 'T'o some three or four of them may be assigned a place-shall we say midway, by courtesy?-on the ledges of Parnassus; the rest are innocent of all altitudes whatsoever, except those of (irub-street garrets, or the stilts of an absurd vanity.

Foremost among the select few, by right of seniority, and perhaps by pretic right as well, we have "I. D.," who in the cool dawn of the seventeenth century, and when the Elizabethan men were passing, one by one, into the shadow, "sang to the echo," (for he seems to have had no other audience in his own day and generation,) these "Secrets of Angling," himself being destined to become a greater secret than any he revealed.

His publisher, "R. J." (Roger Jackson) states, in his dedication of the poem to Mr. John Harborne of Tackley, that the author "intended to have printed it in his life, but was prevented by death." Other motives of reticence, however, besides that final one, may have had their weight: sonle faintness of heart, for instance, and some wisclom of discretion. The epoch was a trying one for the minor muse. The Elizabethan bards, as I have said, were dying out. but the national air stiil vibrated to their divire singing the national heart was still at fever-heat, with "Fairy Queens," and "Passionate Pilgrims," with " licavenly" Unas," and heroic "Lucreces." It would scarcely have been strange. if a poet unknown to fame, had recoiled from bringing into competition with thesc and such as these, a simple song of bleak and bream. But whatever the real motive may have been, I. 1), of a surety closed his eyes on all the shows of this world, if not a "mute," at least an "inglorious" poet, and unconsoled, 
perchance, by the conviction, that his modest rhymes would be brought into favour and acceptance, at a fitting time.

In I6I3, appeared the first edition (rmo.), a pocket volume, with the following title: "The Secrets of Angling. 'Teaching, the choisest Tooles, Baytes and Seasons, for the taking of any Fish, in Pond or Riner: practised and familiarly opened in three Bookes. Iy I. D. Esquire. Printed at London, for Roger Jackson, and are to be sould at his shop neere Fleetstrect Conduit, I613."

In this title is an allegorical wood-cut, representing two men, one treading on a serpent, and with a sphere at the end of his angle, and over his rod a label with this inscription:

"Hold hooke and line Then all is mine."

The other figure has a fish on his hook, and is labelled thus:

"Well fayre the pleasure

That brings such treasure."

At the back of the title is a copy of verses. "In due praise of his praiseworthy skill and worke," signed "Jo Dauies," followed by the dedication we have before alluded to, and which is given with the present reprint.

It is difficult to fix with any certainty, the number of copies extant of this edition. The Bodleian possesses one, Mr. Denison another, and Mr. Huth a third. There are also scme imperfect copies.

Of the second edition " there is, I believe, but one known copy. which is now in the Denison collection. It is supposed (for the date is cut off) to have appeared about 1620 . It was edited by W. Lauson, and the title-page states that it is "augmented with many approved experiments." Lauson's additions to the work are an address "To the reader," and some notes and recipes.

Lauson's address "To the Reader" ran thus:

"It may seeme in me presumption to adde this little comment to the work 1 "Frinted at London for Reger Jackson and are to be son:11-" the res! cut cff. 
of so worthy an author. But Mr. Harrison the stationers request and desire to give his country satisfaction, must be satisfied, and in it myselfe rest excused. What nine observations are, I refer to censure: assuredly the truth stands on so well grounded experience, that but my haste, nothing can do them injury. What to me is doubtful, I have, as I can, explained; what wants, in my judge ment, I have supplied as the time would suffer; what I passe by, I approve. The author by verse hath expressed much learning, and by his Answer to the Objection, shewn himselfe to have been vertuous. The subject itselfe is honest, and pleasant, and sometimes profitable. Use it, and give God all glory. Amen."

In the subsequent issues no important alteration, that $I$ an aware of, was made either in the poem or the notes.

The third edition bore date $1630 ;^{1}$ and the only known copy is in the Denison collection. A new wood-cut is used of the same subject, but badly executed. One motto is the same-the other reads: "Well fare the pleasure that yields such treasure." The fourth appeared in $165^{2.2}$ Several copies of the latter are extant, of which two are in the British Museum and one in the possession of Mr. Denison. The woodcut here figures as a frontispiece and its place in the title is filled with the bookseller's mark, "The Hare and Sun."

The poem was reprinted in extenso, from the preceding edition, in Sir Egerton Brydges' "British Bibliographer," 3 and a hundred copies, with inclex and short advertisement, were struck off separately. It was also noticed, with large citations, in the same bibliophile's "Censura Literaria" 4 in an article which was appropriated by Daniel, in the supplement to his "Rural Sports," in $\mathrm{r}_{1} \mathrm{I}_{3}$.

The fact of the second, third, and fourth editions being distinct, is proved (if any proof were wanting) l)y the variations both in the title and in the leaf containing the mystical recipe-."Wouldst thou take fish?" Thus in the second edition we are told--

"This excellent recipe you may buy ready and truely made at the signe

1 "Printed in Swo for John Jachon in the Strand, at the sign of the Parote. 16 $30 . "$

" "Iondon, printed hy T. II, for Juhn Harrison, and are to be old ly lrancis Coles at his shup at Old Liayley, 1652."

: 1812 , Vol. II. ]. 465 .

+1 Sog, Vol. X. p. 2 So. 
of the Black Lyon an Apothecaries', in Paule's-Churchyard neare the Great South dore."

In the third, we are referred for the same to the "Signe of the Flying Horse an Apothecaries' in Carter Lane."

While the fourth informs us that "This excellent receipt, divers Anglers can tell where you may buy them."

Beloe, speaking of the edition of $\mathbf{r}_{52}$, says, "Perhaps there does not exist in the circle of English literature a rarer book than this." He seems to have ignored the former editions-though how this could have been with Lauson's "Augmented" in the title page, is not clear.

Pickering, in his "Bibliotheca Piscatoria" $(1836)$ also ignores the second and third editions, but rectifies the omission in some MS. addenda to his list, which were once in my possession.

That Mr. Bohn should have been guilty of the same short-coming in his recent reprint of Lowndes, is less excusable, as the fact had become patent to any diligent seeker.

In summing up the editions, we must not omit Mr. Arber's re-issue in his "English Garner," Vol. I. (I877).

The authorship of the "Secrets" remained a vexed question until a comparatively recent period (we believe about $\mathbf{8} 8 \mathrm{II}$ ). It was attributed by Walton to Jo. Davors, Esq., several verses of the poem being quoted, with variations that were not improvements, in his "Compleat Angler." R[obert] H[owlett], in his preface to the "Angler's Sure Guide," (I 706) assigns it to Dr. Donne, whom he styles "that great practitioner, master and patron of Angling," and he adds, "indeed, his seems to be the best foundation of all superstructures of this kind, and upon that basis chiefly have I raised mine."

To one or other of the six poets of the name of Davies, the poem has also been ascribed; but all these conflicting hypotheses were finally set aside by the discovery, in the Registers of the Stationers' Company, of the following entry :-

" I 61 2, Feb. 28th." Mr. Roger Jackson entered for his copie under th'andes of Mr. Mason and Mr. Warden Hooper, a booke called the Secrets of Angling, 
teaching the choycest tooles, baites and seasons for the taking of any fish in pond or river, praktised and opened in three bookes, by John Dennys, Esquire. vjd."

Sir Harris Nicolas, who, in his edition of Walton's Angler (1836) begins by asserting (very gratuitously) that the poem, "though entered in the name of Dennys, is by John Davors," adds a subsequent note of recantation: "There are strong reasons," he says, "for believing that the 'Secrets of Angling,' was not written by John Davors, but by John Dennys Esi]. who was lord of the Manor of Oldbury-sur-Montem, in the County of Gloucester, between 1572 and r608. He was a younger son of Sir Walter Dennys, of Pucklechurch, in that county, by Agnes, daughter and co-heiress of Sir Robert Davers or Danvers. It has been observed by Mr. James Williamson, that the author of the 'Secrets' speaks of the River Boyd as 'washing the cliffs of Deington and Week.' There is, in fact, a beautiful rivulet. called Boyd, which is formed by four distinct streams, rising in the parishes of Codrington, Pucklechurch, Dyrham and Toghill, in the southern part of the County of Gloucester, between Bath and Bristol, which join in Wyke or Week Street, in the parish of Alston and Wyke, near a bridge of three large arches. and thence, by the name of Boyd, descends to Avon, at Kynsham Bridge, and which river passes through the village of Pucklechurch and thence flows on to Bitton. At Alston and Wyke there are many high cliffs or rocks, and in the north Aisle of the Ancient Church of Pucklechurch is the burial place of the family of Dennys. John Dennys was resident in that neighbourhood in the year 1572 , and so continued till I 608 diuring which interval he was lord of the manor of Oldbury-sur-montem, and of other places in the county of Gloucester."

There seems great and serious cause to doubt the accuracy of Sir Harris Nicolas's hypothesis, as given in the above extract.

I was faroured, some time since, by the Rev. H. N. Fllacombe, of Bitton, with a portion of the Dennys pedigree, showing six descents from the Sir Walter in question, and Mr. Fllacombe infers therefrom, and with great show of reason, that the real author of the poem was more probably sir Walter's great-grandson, the John Dennys who was buried at Pucklechurch in I(roo). four years, that is to say. previous to the publication of the rolume. 
The pedigree, as extracted, is as follows:

Sir Walter Dennys.

John Dennys of Pucklechurch.

Hugh Denny;, died 1559.

John Dennys, died 1609, buried at Pucklechurch,

IIenry Dennys, son and heir.

John Dennys elde:t son and heir, died 1638 .

John Dennys owner of Bitton Farm, died 1660.
= Agnes, daughter and heir Robert Davers, or 1)anvers.

= Fortune, widow of $\mathrm{Wm}$. Kemys, of Newport, and daughter of Thos. Norton of Bristol.

$=$ Katherine, daughter of Edw. Trye, of Hardwick, co. of Gloucester; died $\mathrm{I}_{5} \mathrm{~S}_{3}$, at Pucklechurch.

Elianor, or Ilelena, daughter of Thos. Millet, co. Warwick.

= Margaret, daughter of Sir George Spelie, of Whitehackington, co. Somerset.

= Mary, daughter and co-heir of Nat. Still, of Hutton : died 169 s annis plena: buried at Puckle. church.

No date, it will be perceived, is associated with Sir Walter Dennys, but on referring to a more detailed pedigree from the same source, I find that his eldest son, Sir William Dennys, "founded a guild in the year 1520." We may therefore reasonably assign his birth to the latter part of the fifteenth century, or to the very beginning of the sixteenth. These premises are borne out by the fact that John, his second brother, (author of the "Secrets," according to Sir Harris Nicolas) left a son, Hugh Dennys, who died in 1559 , and at no immature age, since he was married and had four offspring. If, therefore, Sir Harris Nicolas's assumption be correct, we must ascribe the poem to the early part, or at the latest, to the middle of the sixteenth century, whereas its.style and general character belong, assuredly, to a later period. Collateral evidence, on the side of Mr. Ellacombe's opinion, is to be found in the fact that R. I. (Roger Jackson) in his dedication, does not throw the poem far back, in a posthumous sense, but merely says:--

"This poem being sent unto me to be printed after the death of the author, who intended to have done it, in his life, but was prevented by death," \&c. \&c.

Had the "Secrets" been in existence half a century, some allusion would surely have been made to the circumstance.

Mr. Carew Hazlitt, in his "Handbook to Early English Literature," cites the bibliography of the book under notice as being "very unsettled." I had 
hoped he would have eontributed something to its settlement. but he leaves it as he found it. "There seem to have been four ellitions," he says, "the second and third undated." I have shown that the unique copy of the sceond is, in all probability, undated, only through the misloing of the binder's knife, and that of the third, a copy is extant aith the date. In Mr. Hazlitt's description of the Bodleian eopy of the first edition, he appears to have been guided by Bohn's Lowndes, for he adopts (as I did myself, in the first instance, from want of evidence) one of the blunders of that authority. 'The copy in question is not Milner's copy, which is thus deseribed in his sale-catalogue :-.. Denny's Serets of Anslinis, a Poem, augmented with many approved Experiments by Lauson, frontispiece, date cut off." This was evidently, therefore, a mutilated copy of the edition of 1652 , in which alone the woodcut figures as a frontispiece. The Hodleian copy, on the contrary, is complete; has no mention of Lauson on the title-page and bears the imprint of $\mathrm{IG}_{3}$. It must have found its way into the library at an earlier (late, for two compilers of Angling-book lists, (in MS.) Mr. White of Criekhowell (in I806-7) and Mr. Appleby (in I820) refer to it. The former states that it was entered under the name of John 1)avies, of hidwelly.

In further corroboration of Mr. Ellacombe's view, I must add that it is adopterl by Mr. Tomkins, a deseendant of the Dennises of Pucklechurch. (Sec Notes and Queries. 4th Scries, Aug. 28th. 1869.)

The only contemporary reeognition of I. 1), that I am aequainted with, is in "the Pleasures of Princes, good mens recreations: containing a discourse of the Generall $\lambda r t$ of Fishing with the Angle or otherwise; and of all the hidden Secrets belonging thereunto. Together with the Choyce, Oidering, Breeding. and Iyeting of the Fighting Cocke," the latter being added, peradventure, for increase of princeliness. This scarce tract is commonly considered to be the transmigration of the "Secrets" into prose. It first appeared with seprarate pagination in "The second booke of the English Husbandman," If I 4 , and in subsequent issues of that work; and was also incorporated with Markham's "Country Contentments," possibly in I 623, but certainly in I6 3 I ant atterwarcs. In the latter form it is entitled: "The whole Art of Angling; as it was written in a smail 'Treatise in Rime, and now, for the better understanding of the Reader, put into Prose and alomed and enlarged." The transmuting process (for there can be little doubt of the correctness of the general surmise) was 
effected by no unskilful hand, and without too much sacrifice of the precious metal of the original. Sir Philip Sidney's ordeal has, indeed, seldom been undergone, with so little deterioration. The quaint character of the poem is preserved in the prose version and the passages added (especially the introduction) have a striking merit of their own.

It is proof of the vitality of Dennys' verse, that it retains its strength, sweetness and savour in its more sober form. Those curious in parallels may compare "The Qualities of an Angler," in the third book of the poem, with chapter 2 (its corresponding passage) of the "Pleasures of Princes."

It is not needful that I should enter on a critical appreciation of this little poem, the finest passages of which are well known and highly esteemed. Thus much, however, may be said, that, so replete is it, in its higher moods, with subtlety of rhythm, sweetness of expression, and elevation of thought and feeling, that even from the angling point of view, we cannot but consider it a notable piece of condescension, and marvel at the devotion of so much real poetic genius to a theme so humble. With the exception of the "Compleat Angler," no higher compliment than this poem has been paid to the sport. Subsequent rhymers, indeed, have achieved analogous feats, but from other heights, or rather from other depths-witness the "Innocent Epicure," a polished piece of artificiality, and often grotesque, by force of polish ; and "The Anglers, Eight Dialogues in Verse," by Scott of Ipswich, in which the technical and humorous are dexterousiy enough interwoven; but such trifling in verse, as these and other poems of their kind display, is not to be confounded for an instant with the art-work and heart-work of John Dennys, (the Angler's "Glorious John") who could not have been more in earnest, had he sung of men and angels; who drapes himself in his singing robes on the very threshold of his theme, as by an assured vocation, and only doffs them with his ultimate line :-

"And now we are arivèd at the last,

In wishèd harbour where we meane to rest;

And make an end of this our journey past;

Here then in quiet roade $I$ think it best

We strike our sailes and stedfast Anchor cast,

For now the sunne low setteth in the west." 
And "in quict roade," in the grey old aisle of Pucklechurch, our poet's rest is won:-

$$
\text { "Such a sleep he sleeps, the man we love!" }
$$

-this man that may have seen the face of Shakespeare, nay, this man that, perchance, fished in his immortal company, the Boyd that he loved and sung so well-the Boyd that still, with "crooked, winding way,"-

"Its mother Avon runneth soft to seek."

1. WESTHOOD. 


\section{ADVERTISEMENT.}

THE present reprint is a strictly faithful and literal transcript of the edition of 1613. It has been our wish to perpetuate the original text as the author bequeathed it to the world. In this respect it differs essentially from Mir. Arber's reprint in his "English Garner." Mr. Arber, on the contrary, has thought it expedient to make many changes in the poem, and to introduce into it frequent supposed emendations. Thus he has altered the punctuation throughout and modernised both the orthography and the syntax, robbing the verse, thereby, of much of its ancient air and aspect. Instead of J. I). in his customary doublet and hose, he has given us a J. D. in the broadcloth of to-day, with all the gloss upon it. How far we have a right so to interfere with poets who are no longer here to defend themselves and to protect their own-how far it is. justifiable, to submit them to our individual and arbitrary, not to say dogmatic, judgment, is a question we do not take on ourselves to decide. What our own personal opinion in the matter is will be deduced from the course we have adopted.

T. W. 



\section{THE}

\section{SECRETS OF ANGLING:}

\section{Tiaching,}

The Choisest Tooles Baytes and seasons, for the taking of any Fish, in P'ond or Riner:

practised and familiarly opened in three Bookes.

BY I. D. ESQUIKL:

Printed at London, for ROGER JACKSON, and are to be sould at his shop neere Fleetstrict Conduit, 1613. 



\section{TO THE WOKTHY, AND \\ MY MVCH RESPECTED FRIEND, \\ MR. JOIIN HARBORNE, OF TACKLEF, IN TIHE \\ COUNTY OF OAFORD, ESQUIRE.}

UPR' SHR,

This Pocme beiug seut into me to be printed after the death of the Author, aho iutended to haue doue it iu his life, but was prenented by death: I could not among my good fricuds, bethinke ne of auy one to whom I might more filly dedicate it (as acll for the uature of the subiect in ailuch you dolight as to expresse uny loue) than to jourselfe.

$I$ finde it uot onely sanouring of Art and Houesty, ta'o things now strangers suto muny Authors, but also both pleasant and profitable; and biing loath to see a thing of such value lye hidden in obscuritie, aluilst matters of wo moment pister the stales of euery STATHNER; I therefore matie bolde to publish it, for the benefit aud dilight of all, trusting that I shatl neithe thereby disparage the Author, noe dislike them.

I necde" uot, I think, Appollogine cither the ase of the subiect, or for that it is rectuced into the nature of a Pocme; for as touching the last (in that it is in icresc) some count it by so much the more dibishtfirll; and

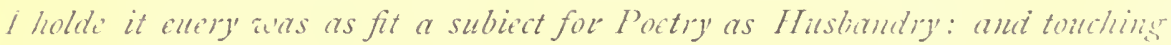
the' first, if Hunting and Ilawking lande be'th thought a'orthy delights arid Artes to be insiructid in, I make uo dould but this art of Ansting is mach more arorthy practisi and afjeolation ; for it is a sport iner"

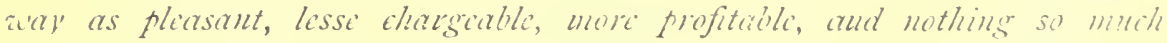
sublict to challer or impatience as those are' l'ou shall finde it indrie briefly. pliasautiy, and exactly pirformed, then any of this hinde herioforit. Thive-

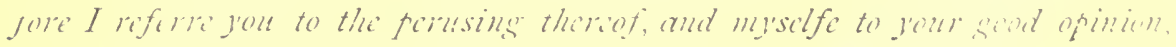

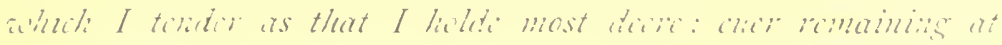




\section{IN DUE PRAISE OF THIS PRAISE-WORTHY SKILL AND WORKE.}

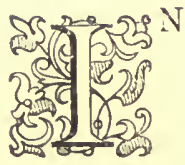

skils that all doe seeke, but few doe finde,
Both gaine and game; (like Sunne and Moone doe shine), Then th' Art of Fishing thus, is of that kinde; The Angler taketh both with Hooke and Line, And as, with Lines, both these he takes; this takes, With many a Line, well made, both Eares and Harts; And, by this skill, the skill-lesse skill-full makes:

The Corpes whereof dissected so he parts,

Vpon an humble Subiect neuer lay,

More proude, yet plainer Lines, the plaine to leade,

This playner Art with pleasure to suruay,

To purchase it, with profit, by that DEED:

Who thinke this skill's too low than, for the high,

This Angler reade, and they'l be tane thereby. 


\section{THE CONTENTS.}

TIE FIRST BOOKE CONTAINETI THESE 3. HEADS.

1. The antiquitie of Angting, with the Art of Fishing, and of Fish in generatl.

2. The lawfuthesse, pleasure and profit thereof, with att Obiections, answered, agrainst it,

3. To know the season, and times to pronide the Tooles, and how to choose thi best, and the manner how to make them fit to take each senterall liish.

TIE, SECOND DOUKL, CONTAINETH

1. The Angters expericine, how to ise his Tootes and Baytes, to make profit by lis game.

2. What Fish is not taken with Angle, and what is; and which is best for health.

3. In what IVaters and Riners to finde cach Fish.

THE THKL BOOKE CONTAIYTH,

1. The 12. sertues and quatities which onght to be in entery Angler.

2. What weather, seasons, and times of the yeire is best and a'oist; and allat houres of the day is liest for sport.

3. To know each Fishes haunt. and the times to take them.

Aso, an obscure secrit, of an affrorid bat, tinding therente. 


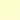


"YHI:

\section{SECRETS \\ of $A N G L I N G$.}

THE FIRST BOOKE.

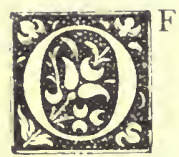

Aisgling, and the Art thereof I sing,

What kincle of 'Tooles it doth behome to hane:

And with what pleasing loyt a man may bring

The Fish to bite within the watly watk.

A worke of thankes to such as in a thing

Of harmlesse pleasure, haue regard to saue

'Their dearest soules from sinne: and may intenl

()f pretious time, some part thereon to spend.

You Nymphs that in the syrings and Waters sweet.

Vóur dweiling hawe, of encery Hill and l)ake,

And oft amidst the Meadows greene doe meet

To sport and play, and heare the Wistingole:

And in the Riuers fresh doe wash your feet.

While Pregrles sister tels her wotull tale:

such ayds and power vinto my rerses lemul.

Is may sufice this little worke to emel. 
And thou sweet Boyd ${ }^{1}$ that with thy watry sway, Dost wash the cliffes of Deington and of ITeeke; And through their Rockes with crooked winding way, Thy mother Auon rumnest soft to seeke:

In whose fayre streames the speckled 'T'rout doth play, The Roche, the Dace, the Gudgin, and the Bleeke.

Teach me the skill with slender Line and Hooke

To take each Fish of River, Pond, and Brooke.

\section{THE TIME FOK PROUIDING ANGLE RODS:}

First, when the Sumne beginneth to decline

Southward his course, with his fayre Chariot bright.

And passed hath of Heauen the middle Line,

'That makes of equall length both day and night;

And left behind his backe the dreadfull signe,

Of cruell Centanre, slaine in drunken fight,

When Beasts do mourne, and Birds forsake their song,

And euery Creature thinkes the night too long.

And blustring Boreas with his chilling cold.

Vnclothed hath the 'Trees of Sommers greene;

And Woods, and groues, are naked to beholkl.

Of Leaues and Branches now dispoyled cleane:

So that their fruitfull stocks they doe vnfold.

And lay abroad their of-spring to be seene;

Where nature shewes her great increase of kinde

To such as seeke their tender shutes to finde.

Then goe into some great Aradian wood,

Where store of anrient Hazels doe abound;

And seeke amongst their springs and tender brood:

Such shutes as are the straightest, long. and round:

And of them all (store rp what you thinke good)

But fairest choose, the smoothest, and most sound;

So that they doe not two yeares growth exceed.

In shape and beautie like the belricke Reed.

1 The name of a Brooke. 
These prune and clense of euery leafe and spray,

Yet leaue the tender top remaining still:

Then home with thee goe beare them safe away,

But perish not the kine and vtter Pill;

And on some euen boarded floore them lay,

Where they may dry and season at their fill:

And place vpon their crooked parts some waight,

To presse them downe, and keepe them plaine and straight.

So shalt thou haue alwayes in store the best,

And fittest Rods to serue thy turne aright;

For not the brittle Cane, nor all the rest,

I like so well, though it be long and light,

since that the Fish are frighted with the least

Aspect of any glittering thing; or white:

Nor doth it by one halfe so well incline,

Is doth the plyant rod to saue the line.

\section{TO MAKE THE LIVE.}

Then get good Hayre, so that it be not blacke,

Neither of Mare nor Gelding let it be ;

Nor of the tyreling Iade that beares the packe:

but of some lusty Horse or Courser free,

Whose bushic tayle. ipon the ground doth tracke,

like blazing Comete that sometimes we see:

From out the mid'st thereof the longest take,

At levsure best your Linkes and lines to make.

Then twist them finely, as you thinke most meet,

By skill or practise easie to le found:

As doth Arachne with her stemier feet;

I raw forth her little thread along the ground:

but not too hard or slacke, the meane is sweet,

Least slacke they snarle, or hard they proue unsomm,

And intermixt with siluer. silke, or golel,

The tender hayres, the hetter so to holi. 
Then end to end, as falleth to their lot, let all your Isinkes in order as they lie Be knit together, with that Fishers knot That will not slip, nor with the wet untie: And at the lowest end forget it not To leaue a Bought or Compasse like an eye,

The Linke that holds your Hooke to hang vinn, When you thinke gond to take it off and on.

Which Linke must neither he so great nor strong, Nor like of colour as the others were;

scant halfe so big, so that it be as long:

Of greyest Hue, and of the soundest Hayre, Least winiles it hangs the liquid waues among The sight thereof, the warie Fish should feare.

Arid at one end a Loope or Compasse fine, To fasten to the other of your line.

\section{CORKE.}

Then take good Corke, as much as shall suffice, For euery Line to make his swimmer fit; And where the midst and thickest parts doth rise, There burne a round small hole quite thorow it: And put therein a Quill of equall size, But take good heed the Corke you do not slit.

Then round or square with Razor pare it neare, Piramid-wise, or like a slender Peare.

The smaller end doth serue to sinke more light, Into the water with the Plummets sway:

The greater swims aloit and stands vpright, To keepe the Line and bayt at euen stay, 'That when the Fish begins to nib and byte, The mouing of the float doth them bewray: 'These may you place upon your Iines at will, And stoppe them witi a white and handsome Quill. 


\section{HOOKISS}

Then buy your Hookes the finest and the best

'That may be had of such as vise to sell,

And from the greatest to the very least

of euery sort picke out and chuse them well,

such as in shape and making passe the rest,

And doe for strength and soundnesse most excell:

Then in a little Boxe of dryest wood

From rust and canker keepe them faire and goud.

That Hooke I loue that is in ecmpasse round,

Like to the print that Perrosus did make,

With homed hoofe rpon Thessalian ground;

From whence forthwith Pirnassus spring out brake.

That doth in pleasant Waters so abound:

Ind of the Mroses of the thirst doth slatie;

Who on his fruitfull bankes doe sit and sine.

That all the world of their swee[t] tunes doth ring.

()r as Thaumantis, when she list to shrowd

Herselfe against the parching sunny ray,

Vnder the mantle of some stormy cloud.

lihere she her sundry colours doth displit!

I,ike Iunoes bird, of her faire garments proud.

That Plachus gaue her on her marriage day:

Shewes forth her goodly (uircle farre and wille

To mortall wights that wimler at her pride.

His Shank should neither be tom short nor lons:

llis point not oucrsharpe, nor yet tor alull:

The substance good that may indure from wrons.

His Veedle slender, yet both round and full,

Marle of the riglit flicrian mettell strong,

That will not stretch nor bieake at ctury pull.

Wrought smooth and cleane withuuten cran he or hnot

And bearled like the wilele irolitum sout. 
Then let your Hooke be sure and strongly plaste Vnto your lowest Linke with Silke or Hayre, Which you may doe with often ouercaste, So that you draw the Bouts together neare, And with both ends make all the other fast, That no bare place or rising knot appeare:

Then on that Linke hang Leads of euen waight To raise your floate, and carry down your baite.

Thus have you Rod, Line, Float and Hooke;

The Rod to strike, when you shall thinke it fit, The Line to lead the Fish with wary skill, The Float and Quill to warne you of the bit; The Hooke to hold him by the chap or gill, Hooke, Line, and Rod, all guided to your wit. Yet there remaines of Fishing tooles to tell, Some other sorts that you must haue as well.

\section{OTHER FISHING TOOLES.}

A little Boord, the lightest you can finde, But not so thin that it will breake or bend; Of Cypres sweet, or of some other kinde, That like a Trenchor shall itselfe extend:

Made smooth and plaine, your Lines thereon to winde, With Battlements at euery other end:

Like to the Bulwarke of some ancient Towne As well-wald Sylchester now razed downe.

A Shooe to beare the crawling Wormes therein, With hole aboue to hang it by your side, A hollow Cane that must be light and thin, Wherein the Bobb and Palmer shall abide, Which must be stopped with an handsome pin, Least out againe your baytes doe hap to slide. A little Box that couered close shall lye, To keepe therein the busic winged Flye. 
Then must you haue a Plummet, formed round,

like to the Pellet of a birding bow:

Wherewith you may the secret'st waters sound,

And set your floate thereafter high, or low,

'Till you the depth thereof haue truly found:

And on the same a twisted thread bestow

At your owne will, to hang it on your hooke,

And so to let it downe into the Brooke.

Of Lead likewise, yet must you haue a Ring,

Whose whole Diameter in length containes

Three Inches full, and fastned to a string.

That must be long and sure, if need constraines:

Through whose round hole you shall your Angle bring,

And let it fall into the watry playne:

Vntill he come the weedes and stickes rnto,

From whence your hooke it serueth to indo.

Hatle Tooles good store to serue your turne withall,

Least that you happen some to lose or breake;

As in great waters oft it doth befall,

When that the Hooke is nought or Line too weake.

And waxed thread, or silke, so it be small,

'I'o set them on, that if you list to wreake

Your former losse, you may supply the place,

And not returne with sorrow and disgrace.

Haue twist likewise, so that it be not white.

You Rod to mend, or broken top to tye;

for all white colours doe the Fishes fright

And make them from the bayte away to flye;

A File to mend your hookes, both small and light.

A good sharpe knife, your (irclle hanging by:

A l'ouch with many parts and purses thin.

To carry all your 'Tooles and Trynkets in. 
Yet must you haue a little Rip beside Of Willow twigs, the finest you can wish;

Which shall be made so handsome and so wide As may containe good store of sundry Fish :

And yet with ease be hanged by your side, To bring them home the better to your dish.

A little Net that on a Pole shall stand, 'The mighty Pike or heauy Carpe to Land.

HIS SEUERALL TOOLES, AND IHAT GARMENT IS FITTEST.

And let your garments Russet be or gray, Of colour darke, and hardest to descry:

That with the Raine or weather will away, And least offend the fearefull Fishes eye:

For neither Skarlet nor rich cloth of ray

Nor colours dipt in fresh Assyrian dye,

Nor tender silkes, of Purple, Paule, or golde,

Will serue so well to keepe off wet or cold.

In this aray the Angler good shall goe

Vnto the Brooke, to finde his wished game;

Like old Menalcus wandring to and fro, Vntil he chance to light vpon the same, And there his art and cunning shall bestow, For euery Fish his bayte so well to frame, That long ere Phalus set in Westerne fome, He shall returne well loaden to his home.

OBIECTION.

Some youthfull Gallant here perhaps will say

This is no pastime for a gentleman.

It were more fit at cardes and dice to play;

To use both fence and dauncing now and than,

Or walke the streetes in nice and strange Aray,

Or with coy phrases court his Mistris fan,

A poore delight with toyle and painfill watch,

With losse of time a silly Fish to catch. 
What pleasure can it be to walke about, The fields and meades in heat or pinching coid?

And stand all day to catch a silly frout,

That is not worth a teaster to be sold,

And peraduenture sometimes goe without,

Besides the toles and troubles manifold, And to be washt with many a showre of ragn: Before he can returne from thence again?

More ease it were, and more delight I trow, In some sweet house to passe the time crray, Amongst the best, with braue and gallant show, And with faire dames to daunce, to sport and ylay, And on the board, the nimble dice to throw, That brings in gaine, and helps the shot to pay, And with good wine and store of dainty fare, To feede at will and take but little care.

\section{THE ANSWERE.}

I meane not here mens errours to reprote, Nor do enuie their seeming happy state;

But rather meruaile why they doe not loue An honest sport that is without debate; Since their abused pastimes often moue

Their mindes to anger and to mortall hate:

And as in bad delights their time they spend, So oft it brings them to no better end.

Indeed it is a life of kesser paine.

To sit at play from noone till it be night:

And then from night till it be noone againe.

With damned oathes, pronounced in despight,

For little cause and euery trille vaine,

'To curse, to brawle, to quarreil, and to figint,

To packe the cardes, and with some comning tricke.

His fellowes Parse of all his coyne 10 pircke. 
Or to beguile another of his Wife,

As did Aighistus Agamemnon serue:

Or as that Roman ${ }^{1}$ monarch led a life

To spoil and spend, while others pine and sterue,

And to compell their friends with foolish strife,

To take more drinke then will their health preserue :

And to conclude, for debt or iust desart,

In baser tune to sing the Counter-part.

O let me rather on the pleasant Brinke

Of Tyne and Trent possesse some dwelling-place;

Where I may see my Quill and Corke downe sinke,

With eager bit of Barbill, Bleike, or Dace:

And on the World and his Creator thinke,

While they proud Thais "painted sheat imbrace.

And with the fume of strong Tobacco's smoke,

All quaffing round are ready for to choke.

Let them that list these pastimes then pursue, And on their pleasing fancies feerle their fill;

So I the Fields and Meadowes greene may vicw, And by the Riuers fresh may walke at will, Among the Dayzes and the Violets blew :

Red Hyacinth and yealow Daffadill, Purple Narcissus, like the morning rayes, Pale Ganderglas and azour Culuerkayes.

I count it better pleasure to behold

The goodly compasse of the loftie Skye, And in the midst thereof like burning gold The flaming Chariot of the worlds great eye;

The watry cloudes that in the ayre vprold W:th surdry kindes of painted collours flie:

And fayre Aurora lifting vp her head, And blushing rise from old Thitonus berl. 
The hills and Mountaines raised from the Plaines,

The plaines extended leuell with the ground,

The ground deuided into sundry vaines,

The vaines inclos'd with running riuers rounde, The riuers making way through natures chaine, With headlong course into the sea profounde:

The surging sea beneath the valleys low,

The valleys sweet, and lakes that lonely flowe.

The lofty woods the forrests wide and long, Adornd with leaues and branches fresh and greene, In whose coole bow'rs the birds with chaunting song,

Doe welcome with thin quire the Summers Queene, The meadowes faire where Flora's guifts among, Are intermixt the verdant grasse betweene, The siluer skaled fish that softlie swimme, Within the brookes and Cristall watry brimme.

All these and many more of his creation, That made the heauens, the Angler oft doth see, And takes therein no little delectation, To think how strange and wonderfull they be, Framing thereof an inward contemplation, 'To set his thoughts from other fancies free, And whiles hee lookes on these with ioyfull eye, His minde is rapt aboue the starry skye.

$$
\text { THE AUTHOR OF ANGLINC: }
$$

But how this Art of Angling dicl beginne, And who the vise thereof and practise found, How many times and ages since haue bin, Wherein the sunne hath dayly compast round. The circle that the signes twice sixe are in: And yeelded yearely comfort to the ground, It were too hard for me to bring abuut, Since Oudi wrote not all that story out. 
Yet to content the willing Readers eare, I will not spare the sad report to tell, When good Deucalion and his Pirrha deere, Were onely left vpon the earth to dwell Of all the rest that onerwhelmed were With that great floud, that in their dayes befell, Wherein the compasse of the world so round, Both man and beast with waters deepe were droun!!

Between themselues they wept and made great moane, How to repaire againe the wofull fall, Of all mankinde, whereof they two alone The remnant were, and wretched portion small, But any meanes or hope in them was none, That might restore so great a losse with all, Since they were aged, and in yeares so runne, That now almost their threed of life was spunne.

Vntill at last they saw where as there stood An ancient Temple, wasted and forlorne; Whose holy fires and sundry offerings good, The late outragious waues away had borne: But when at length downe fallen was the flood, The waters low it proudly gan to scorne.

Vnto that place they thought it best to goe, The counsell of the Goddesse there to know.

For long before that fearfull Deluge great, The vniuersall Earth had ouerflowne;

A heamenly power there placed had her seate, And answeres gate of hidden things vnknowne. Thither they went her fauour to intreat, Whose fane throughout that coast abroad was blowne.

By her aduice some way or meane to finde, How to renew the race of humane kind. 
Prostrate they fell vpon the sacred ground,

Kissing the stones, and shedding many a teare;

And lowly bent their aged bodies downe

Vnto the earth, with sad and heauy cheare;

l'raying the Saint with soft and dolefull sound

That she vouchsafe their humble suite to heare.

The Goddesse heard, and bad them goe and take.

Their mothers bones, \& throw behind their barke.

'This Oracie' obscure, and darke of sence,

Amazed much their mindes with feare and doubt,

What kind of meaning might be drawne from thence;

And how to vnclerstand and finde it out,

How with so great a sinne they might dispense

Their Parents bones to cast and throw about:

Thus when they had long time in studie spent,

Out of the Church with carefull thought they went.

And now beholding better euery place,

Each Hill and Dale, each Riuer, Rock, and Tree;

And muzing thereupon a little space,

They thought the Earth their mother well might be.

And that the stones that lay before their face,

To be her bones did nothing disagree:

Wherefore to prove if it were false or true,

'The scattered stones lehind their backs they threw.

Forthwith the stones (a wondrous thing to heare)

Began to moue as they had life conceiu'd, And waxed greater than at first they were:

And more and more the shape of man receiu'd, Till euery part most plainely did appeare,

'That neither eye nor sence could be deceilid:

They hearl, they spake. they went, and waiked too,

As other liuing men are wont to doe. 
Thus was the earth replenished a new

With people strange, sprung vp with little paine,

Of whose increase the progenie that grew,

Did soone supply the empty world againe;

But now a greater care there did insue,

How such a mightie number to maintaine,

Since foode there was not any to be found,

For that great flood had all destroyd and drownd.

Then did Deucalion first the Art inuent

Of Angling, and his people taught the same;

And to the Woods and groues with them hee went

Fit tooles to finde for this most needfull game;

There from the trees the longest ryndes they rent,

Wherewith strong Lines they roughly twist and frame,

And of each crooke of hardest Bush and Brake,

They made them Hookes the hungry Fish to take.

And to intice them to the eager bit,

Dead frogs and flies of sundry sorts he tooke;

And snayles and wormes such as he found most fit,

Wherein to hide the close and deadly hooke:

And thus with practise and inuentiue wit,

$\mathrm{He}$ found the mieanes in euery lake and brooke

Such store of Fish to take with little paine.

As did long time this people new sustaine.

In this rude sorte began this simple Art, And so remain'd in that first age of old, When Saturne did Amaltheas horne impart

Vnto the world, that then was all of Gold;

The Fish as yet had felt but little smart,

And were to bite more eager, apt. and bold:

And plentie still supplide the place againe

of woefull want, whereof we now complaine. 
But when in time the feare and dread of man

Fell more and more on every liuing thing,

And all the creatures of the worth beran

To stand in awe of this vsurping King,

Whose tyranny so farre extended than

That Earth and seas it did in thraldome bring;

It was a worke of greater paine and skill,

The wary Fish in lake or brooke to kill.

So worse and worse two ages more did passe,

Yet still this Art more perfect daily grew,

For then the slender Rod inuented was,

Of finer sort than former ages knew,

And Hookes were made of siluer and of brasse,

And Lines of Hempe and liaxe were framed ncw;

And sundry baites experience lound sut more,

Then elder times did know or try before.

I3ut at the last the Iron age drew necre,

Of all the rest the hardest, and most scant,

Then Iines were made of Silke and subtile bayre

And Rods of lightest Cane and Hazell plant,

And Hookes of hardest steele inumted were,

That neither skill nor workemanship did want, .

And so this Art did in the end attaine

Vnto that state where now it doth remaine.

But here ny weary Ifuse a white mus he.t.

That is not veed to so long a way;

Ind breath, or pause a little at the least

It this Lands end, vntill another ciay,

ind then againe, if so she thinke it best:

Our taken-taske afresh wee will assay,

And forwarl goe as first we ciid intenel,

Till that wee come rnto our iouneyes ent?

The cind of the fint liuth. 


\section{THE SECOND BOOKE.}

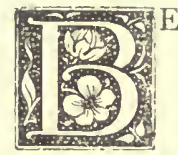

EFORE, I taught what kinde of 'I'ovles were fit For him to haue that would an Angler be :

And how he should with practise and with wit

Prouicie himselfe thereof in best degree:

Now doth remaine to shew how to the bit

The Fishes may be brought, that earst were free, And with what pleasing baits intis'd they are,

To swallow downe the hidden Hooke vnware.

\section{BAITES.}

It were not meet to send a Huntsman out Into the Woods, with Net, with Gin, or Hay, 'To trace the brakes and bushes all about, The Stag, the Foxe, or Badger to betray: It hauing found his game, he stand in doubt Which way to pitch, or where his snares to lay, And with what traine he may entise withall The fearfull beast into his trap to fall.

So, though the Angler haue good store of tooles, And them with skill in finest sort can frame; Yet when he comes to Riuers, Lakes, and Pooles, If that he know not how to vse the same, And with what baits to make the Fishes fooles, He may goe home as wise as out he came, And of his comming boast himselfe as well As he that from his fathers Chariot fell. 
Not that I take upon mee to impart

More then by others hath before beene told:

Or that the hidden secrets of this Art

I would into the vulgar sort vnfolde,

Who peraduenture for my paines desart

Would count me worthy Balams horse to holde:

But oncly to the willing learner show

So much thereof as may suffise to know.

But here, O Neptune, that with triple Mace

Dost rule the raging of the Ocean wide;

I meddle not with thy deformed race

Of monsters huge, that in those waues abide:

With that great Whale, that by three whole dayes space

The man of God did in his belly hide,

And cast him out vpon the Euxin shore

As safe and sound as he had beene before.

Nor with that Orke that on Ceflucan strand Would have deuour'd Andremeda the faire,

Whom Perseus slew with strong and valiant hand,

Deliuering her from danger and despaire,

The Hurlepeole huge that higher then the land,

Whole streames of water spouteth in the ayre,

The Porpois large that playing swims on hie,

Portending stormes or other tempest nit.

Nor that admirer of sweet Musickes sound.

That on his backe Arion bore away;

And brought to shore out of the Seas profound.

The Hiffotame that like an horse doth neigh,

'The Mors, that from the rockes inrolled round,

Within his teeth himself doth safe conuay:

The Toriolise couered with his tarect hard.

The Tulerene attenderl with his guarel. 
Nor with that Fish that beareth in his snout A ragged sword, his foes to spoile and kill; Nor that fierce Thrasher, that doth fling about His nimble flayle, and handles him at will: The rauenous Sharke that with the sweepings out And filth of ships doth oft his belly fill;

The Albacore that followeth night and day The flying Fish, and takes them for his pray.

The Crocodile that weepes when he doth wrong.

'The Hollilut that hurts the appetite,

The Turbut broad, the Sceale, the Sturgion strong.

The Cod and Cozze, that greedy are to bite, The Haake, the Haddocke, and Conger long, The yeallow Ling, the Milzuell faire and white,

The spreading Ray', the Thomback thin and flat, The boysterous Base, the hoggish Tunny fat.

These kindes of Fish that are so large of sise, And many more that here I leaue vntolde Shall goe for me, and all the rest likewise 'That are the flocke of Proteus watry folde: For well I thinke my Hookes wovld not suffise, Nor slender Lines, the least of these to holde.

I leaue them therefore to the surging Seas:

In that huge depth, to wander at their ease.

And speake of such as in the fresh are found, The little Roach, the Menise biting fast, The slymie Tench, the slender Sinclt and round, The Umber sweet, the Graueling good of taste, The wholesome Ruffe, the Barbill not so sound, The Pearch and Pike that all the rest doe waste, 'The Bream, the Carpe, the Chull, and Chauendar, And many more that in fresh waters are. 
Sit then Thalia on some pleasant banke, Among so many as fair Auon hath, And marke the Anglers how they march in ranke, Some out of Bristoll, some from healthfull Bath; How all the Riuers sicles along they flanke, And through the Meadowes make their wonted path:

See how their wit and cunning they apply, 'To catch the Fish that in the waters lye.

\section{FOR THE GOODGION.}

Loe, in a little Boate where one cloth stand, That to a Willow Bough the while is tide, And with a pole doth stirre and raise the sand; Where as the gentle streame doth softly glide, And then with slender Line and Roul in hand, The eager bit not long he doth abide.

Well leaded is his Line, his Hooke but small,

A good big Corke to beare the streame withall.

His baite the least red worme that may be found, And at the bottome it doth ahwayes lye;

Whereat the greedy Goodgion bites so sound

That Hooke and all he swalloweth by and by:

See how he strikes, and puls them rp as round As if new store the play did still supply.

And when the bit doth dye or bad doth proue,

Then to another place he doth remoue.

This Fish the fittest for a learner is That in that Art delights to take some paine;

For as high flying Haukes that often misse The swifter foules, are eased with a traine.

So to a young begimner yeelleth this,

Such readie sport as makes him proue againe.

And leacles him on with hope and glad desire; 'T'o greater skill, and cunning to aspire. 


\section{FOR THE ROCHE}

Then see on yonder side, where one doth sit

With Line woll twisted, and his Hooke but small;

His Corke not big, his Plummets round and fit,

His bayt of finest paste, a little ball

Wherewith he doth intice vnto the bit,

The careless Roche, that soone is caught withall:

Within a foote the same doth reach the ground.

And with least touch the float straight sinketh downe.

And as a skilfull Fowler that doth vse

The flying Birds of any kinde to take,

The fittest and the best doth alwayes chuse,

Of many sorts a pleasing stale to make,

Which if he doth perceiue they doe refuse,

And of mislike abandon and forsake,

To win their loue againc, and get their grace

Forthwith doth put another in the place.

So for the Roach more baites he hath beside, As of a sheepe the thicke congealed blood, Which on a board he vseth to deuide

In portions small, to make them fit and good, That better on his hooke they may abide:

And of the waspe the white and tender brood, And wormes that breed on euery hearbe and tree, And sundry flies that quicke and liuely be.

$$
\text { FOR THE DACE. }
$$

Then looke where as that Poplar gray doth grow, Hard by the same where one doth closely stand, And with the winde his Hoolie and bayt doth throw Amid the streame with slender hazell wand, Where as he sees the Dace themselues doe show, His eye is quicke, and ready is his hand, And when the Fish doth rise to catch the bayt, He presently doth strike, and takes her strayt. 
O worlds deceit! how are we thrald by thee, Thou dost thy gall in sweetest pleasures hicle?

When most we thinke in happiest state to be, Then doe we soonest into danger slide, Behold the Fish that euen now was free. Vnto the deadly hooke how he is tide, So vaine delights alure vs to the snare, Wherein vnwares we fast intangied are.

\section{FOR THE CARPE.}

Bvt now againe see where another stands, And straines his rod that double seemes to bencl, Loe how he leades and guides him with his hands, Least that his line should breake or Angle rend, Then with a Net see how at last he lands, A mighty Carfe and has him in the end, so large he is of body, scale, and bone, That rod and all had like to have beene gone.

Marke what a line he hath, well macle and strong,

Of Buccphall, or Bayarils strongest hayre,

Twisted with greene or watched silke among,

Like hardest twine, that holds th' intangled Deare,

Not any force of Fish will doe it wrong,

In Tyne, or Thut, or Thame he needes not feare:

The knots of euery lincke are knit so sure,

That many a plucke and pull they may indure.

His corke is large, made handsome, smooth, and fine, The leads according, close and fit, thereto, A good round hooke set on with silken twine, That will not slip nor easily vndoe:

His bait great wormes that long in mosse haue bin, Which by his side he heareth in a shooe.

Or paste wherewith he feeles him oft before. That at the bottom lyes a foote or mole. 


\section{FOR TIIE CHUB AND TROUT.}

See where another hides himselfe as slye, As did Acteon, or the fearefull Deere;

Behinde a withy, and with watchfull eye

Attends the bit within the water cleere,

And on the top thereof doth moue his flye,

With skilfull hand, as if he liuing were.

Loe how the Chub, the Roche, the Dace, and Trout,

To catch thereat doe gaze and swimme about.

His Rod, or Cane, made darke for being seene, The lesse to feare the warie Fish withall:

The Line well twisted is, and wrought so cleane That being strong, yet doth it shew but small, His Hooke not great, nor little, but betweene, That light vpon the watry brimme may fall, The Line in length scant halfe the Rod exceedes, And neither Corke, nor Leade thereon it needes.

\section{FOR THE TROUT, AVD EELE.}

Now see some standing where the streame doth fall,

With headlong course behind the sturdy weere,

That ouerthwart the riuer, like a wall,

The water stops, and strongly vp doth beare,

And at the Tayles, of Mills and Arches small,

Where as the shoote is swift and not too cleare,

Their lines in length not twice aboue an ell,

But with good store of lead and twisted well.

Round handsome hookes that will not breake nor bend, The big red worm, well scowred, is their bayte, Which downe vinto the bottome doth discend,

Whereas the Trout and Eele doth lye in wayte, And to their feeding busily intend,

Which when they see they snatch and swallow straight. Vpon their lines are neither Corke nor Quill, But when they feele them plucke then strike they stil. 


\section{FOR THE SLIWATT AN FLOUNDER.}

Behold some others ranged all along, To take the Serwant, yea, the Flounder sweet, That to the banke in deepest places throng, To shunne the swifter streame that runnes so fleete, And lye and feede the brackish waues among, Whereas the waters fresh and salt doe meete:

And there the Eele and Shad sometimes is caught, That with the ticle into the brookes are brought.

But by the way it shall not be amisse, To vnderstand that in the waters yray, Of floating Fish, two sundry kindes there is, The one that liues by rauen and by pray, And of the weaker sort, now that, now this, He bites, and spoyles, and kills, and beares away, And in his greedy gullet doth deuowre, As Scillas gulfe, a ship within his powre.

And these have wider mouths to catch and taki 'Their flying pray, whom swiftly they pursew, And rows of teeth like to a saw or rake,

Wherewith the gotten same they bite and chew, And greater speede within the waters make, 'To set vpon the other simple crew, And as the grayhound steales vpon the harc, So doe they ve to rush on them rnware.

Vinerjuall Fate, that some are borne to be Fearfull and milde, and for the rest a pray, And others are ordain'd to liue more free. Without controule or danger any way: So doth the Foxe the lambe lestroy we see, 'The lyon fierce, the bivit, Rete, or Grayl.

The Houke, the foule, the steater wrons the lesse. The lofty proul, the lowly poure oplecese. 


\section{FOR THE PIKE OR PEARCH.}

Now for to take these kinde of Fish with all, It shal be needfull to haue still in store, Some liuing baites as Bleiks, and Roches small, Goodgion, or Loach, not taken long before, Or yealow Frogges that in the waters craule, But all aliue they must be euermore:

For as for baites that dead and dull doe lye, They least esteeme and set but little by.

But take good heed your line be sure and strong, The knots well knit, and of the soundest hayre, Twisted with some well coloured silke anong, And that you haue no neede your Rod to feare: For these great Fish will striue and struggle long, Rod, line, and all into the streame to beare.

And that your hooke be not too small and weake, Least that it chance to stretch, or hap to breake.

And as in Arden or the mountaines hoare, Of Appemmie [Apennine] or craggy Alps among, The mastifes fierce that hunt the bristled Boare, Are harnesed with ${ }^{y}$ Curats light and stronge, So for these Fish, your line a foote or more, Must armed be with thinnest plate along, Or slender wyre well fastned thereunto, That will not slip nor easily indoe.

The other kinde that are vnlike to these Doe liue by corne or any other seede: Sometimes by crummes of bread, of paste or cheese, Or grassehoppers that in greene meadows breed, With brood of waspes, of hornets, doares or bees, Lip berries from the bryar bush or weede, Bloud wormes, and snayles, or crauling Ientiles small, And buzzing flies that on the waters fall. 
All these are good, and many others more,

To make fit baites to take these kinde of Fish, So that some faire deepe place you feede before, A day or two, with paile, with bole, or dish; And of these meats do vse to throw in store, Then shall you haue them byte as you would wish:

And ready sport to take your pleasure still, of any sort that best you like to kill.

Thus seruing then as often as you may, liut once a weeke at least it must be done, If that to bite they make too long delay, As by your sport may be perceinerl soone: Then some great Fish doth feare the rest away, Whose fellowship and companie they shunne:

Who neither in the bait doth take delight, Nor yet will suffer them that would to byte.

For this you must a remedie prouide, Some Rocke or Bleike, as I have shew'd before, Beneath whose vpper fin you close shall hide Of all your Hooke the better halfe and more, And though the point appeare or may be spide, It makes no matter any whit therefore:

But let him fall into the watry brimme, And downe vnto the bottome softly swimme.

And when you see your Corke begin to moue, And round about to soare and fetch a ring, Sometime to sinke, and sometime swimme aboue, As cloth the I)ucke within the watry spring, Yet make no haste your present hap to proue, Till with your float at last away hee fling, Then may you safely strike and hold him short. And at your will prolong or end your sport. 
But euery Fish loues not each bayte alike, Although sometime they feede vpon the same; But some due one, and some another seeke, As best vnto their appetite doth frame, The Roche, the Bream, the Carpe, the Chub, and Bleik, With paste or Corne their greedy hunger tame, The Dace, the Ruffe, the Goodgion and the rest, The smaller sort of crawling wormes loue best.

The Chauender and Chub doe more delight To feede on tender Cheese, or Cherries red, Blacke snayles, their bellies slit to shew their white, Or Grashoppers that skip in euery Meade; The Pearch, the Tench, and Eele, doe rather bite At great red wormes, in Field or Garden bred, That haue beene scowr'd in mosse or Fenell rough, To rid their filth, and make them hard and tough.

And with this bayte hath often taken bin

The Salmon faire, of Riuer-fish the best;

The Shad, that in the Spring time commeth in, The Suant swift, that is not set by least,

The Bocher sweet, the pleasant Flounder thin, The Peele, the Trueat, the Botling, and the rest, With many more, that in the deepe doth lye Of Auon, Vske, of Seuerne and of Wye.

Alike they bite, alike they pull downe low The sinking Corke that striues to rise againe, And when they feele the sudden deadly blow, Alike they shunne the danger and the paine; And as an arrow from the Scithian bow, All flee alike into the streame amaine, Vntill the Angler by his wary skill, There tyres them out, and brings them up at will. 


$$
\text { The Sicrets of Ingling. }
$$

Yet furthermore it doth behoue to know, That for the most part lish doe secke their foode Vpon the ground, or deepest bottome low, Or at the top of water, streame, or flooul; And so you must your hooke and bayte bestow, For in the midst you shall doe little good, For heauie things downe to the bottom fall, And light doe swim, and seldome sinke at all.

All Summer long aloft the Fishes swimme, Delighted with faire Phabus shining ray, And lye in wayte within the waters dimme For flyes and gnats that on the top doe play; Then halfe a yard beneath the vpper brimme It shall be best your bayted Hooke to lay, With gnat or fly of any sort or kinde, That euery Moneth on Icauss or 'Trees you finde.

But then your Line must haue no lead at all, And but a slender Corke, or little Quill, To stay the bayte that downe it doe not fall, But hang a Linke within the water still, Or else vpon the top thereof you shall With quicker hand, and with more ready skill

Let fall your flye, and now and then remoue, Which soone the Fish will finde and better loue.

And in the streame likewise they vse to be At tailes of floudyates, or at Arches wide; Or shallow flats, whereas the waters free With fresher springs and swifter course doe slide: And then of Waspe, the brood that cannot tlye Vpon a Tyle-stone first a little dryed, Or yealow bobs tumed vp before the Plough, Are chiefest lnyts, with Corke and learl enough. 
But when the golden Chariot of the Sunne, Departing from our Northern countries farre Beyond the ballance, now his course hath runne And goes to warme the cold Antarticque starre, And Summers heat is almost spent and done, With new approach of Winters dreadfull warre: Then doe the Fish withdraw into the cleepe, And low from sight and cold more close doe keepe.

Then on your Lines you may haue store of Lead, And bigger Corkes of any size you will, And where the Fish are vsed to be fed There shall you lay vpon the bottom still, And whether that your bayte be Corne, or bread, Or Wormes, or Paste, it doth not greatly skill, For these alone are to be vsed then, Vntil the spring or summer come againe.

Thus haue I shew'd how Fish of diuers kinde Best taken are, and how their bayts to know; But Proxbus now beyond the westerne Inde: Beginneth to descend and draweth low, And well the weather serues and gentle winde Downe with the tide and pleasant streame to row, Vnto some place where we may rest vs in, Vntill we shall another time begin.

The end of the second Book. 


\section{THE THIRD BOOK.}

7ef $O W$ fals it out in order to declare, 10. What time is best to Angle in aright;

(6. And when the chiefe and fittest seasons are

Wherein the fish are most dispos'd to bite, What winde doth make, and which againe doth marre, The Anglers sport, wherein he takes delight, And how he may with pleasure best aspire, Vnto the wished end of his desire.

For there are times in which they will not bite. But doe forbeare and from their foode refraine, And dayes there are wherein they more delight To labour for the same and bite amaine; So, he that can those seasons finde aright Shall not repent his trauell spent in vaine,

To walke a mile or two amidst the fields, Reaping the fruit this harmlesse pleasure yeelds.

And as a ship in safe and quiet roade

Vnder some hill or harbour doth abide, With all her fraight, her tackling, and her load, Attending still the winde and wished tide, Which when it serues, no longer makes aboacl, But forth into the watry decpe doth slicle.

And through the waues diuides her faircit way

Into the place where she intends to stay. 
So must the Angler be prouided still, Of diuers tooles, and sundry baytes in store; And all things else pertaining to his skill, Which he shall get and lay vp long before, That when the weather frameth to his will, Hee may be well appointed euermore

To take fit time when it is offered euer, For time in one estate abideth neuer.

\section{THE QUALITIES OF AN ANGLER.}

Bvt ere I further goe, it shall behoue

To shew what gifts and qualities of minde Belongs to him that doth this pastime loue; And what the vertues are of euery kinde Without the which it were in vaine to proue, Or to expect the pleasure he should finde, No more than he that hauing store of meate Hath lost all lust and appetite to eate.

For what auails to Brooke or Lake to goe, With handsome Rods and Hookes of diuers sort, Well twisted Lines, and many trinkets moe, To finde the Fish within their watry fort, If that the minde be not contented so, But wants great gifts that should the rest support.

And make his pleasure to his thoughts agree, With these therefore he must endued be.

'The first is Faith, not wauering and rnstable, But such as had that holy Patriarth old. That to the highest was so acceptable As his increase and of-spring manifolde Exceeded far the starres innumerable, So must he still a firme perswasion holde,

That where as waters. brookes, and lakes are found. There store of Fish without all doubt abound. 


$$
\text { The Secrets of Angling. }
$$

For nature that hath made no emptie thing,

But all her workes doth well and wisely frame,

Hath fild each Brooke, each Riuer, Lake and Spring

With creatures, apt to lite amidst the same;

Euen as the earth, the ayre, and seas doe bring

Forth Beasts, and lirds of sundry sort and name,

And given them shape, ability, and sence,

'To liue and dwell therein without offence.

'The second gift and qualitie is Hope,

'The anchor-holde of cuery hard desire;

That hauing at the day so large a scope,

He shall in time to wished hap aspie,

And ere the Sunne hath left the heau'niy cope,

Obtaine the sport and game he doth desire,

And that the Fish though sometime slow to bite.

Will recompence delay with more delight.

The third is Lous, and liking to the gane,

And to his friend and neighbour dwelling by;

For greedy pleasure not to spoile the same,

Nor of his Fish some portion to deny

To any that are sicklie, weake, or lame.

But rather with his Line and Ingle try

In Pond or brooke, to doe whit in him lyes,

'To take such store for them as may suffice.

Then followeth Patience, that the furious flame

Of Choller cooles, and l'assion puts to flight,

As doth a skilfull rider breake and tame,

The Courser wilde, and teach him tread aright:

So patience doth the minde dispose and frame,

'To take mishaps in worth, a'nel count them light,

As losse of lish, line. Hooke, or I.ead, or alt.

Or other chance that often may befalt. 
The fift good guift is low Humilitie, As when a lyon coucheth for his pray So must he stoope or kneele vpon his knee, To saue his line or put the weedes away, Or lye along sometime if neede there be, For any let or chance that happen may, And not to scorne to take a little paine, To serue his turne his pleasure to obtaine.

The sixt is painefull strength and courage good, The greatest to incounter in the Brooke, If that he happen in his angry mood, To snatch your bayte, and beare away your Hooke.

With wary skill to rule him in the Flood Vntill more quiet, tame, and milde he looke, And all aduentures constantly to beare, That may betide without mistrust or feare.

Next vnto this is Liberalitie, Feeding them oft with full and plenteous hand, Of all the rest a needfull qualitie, To draw them neere the place where you will stand, Like to the ancient hospitalitie,

That sometime dwelt in Albions fertile land, But now is sent away into exile, Beyond the bounds of Issabellas Ile.

The eight is knowledge how to finde the way To make them bite when they are dull and slow, And what doth let the same and breedes delay, And euery like impediment to know, That keepes them from their fuode and wanted pray, Within the streame, or standing waters low, And with experience skilfully to proue, All other faults to mend or to remoue. 
The ninth is placabilitie of minde,

Contented with a reasonable lish,

Yea though sometimes no sport at all he finde,

Or that the weather proue not to his wish.

The tenth is thankes to that Cool, of each kincle,

To net and bayt doth send both foule and Fish,

And still reserue inough in secret store,

To please the rich, and to relieue the poore.

Th' eleauenth good guift and hardest to influre,

Is fasting long from all superfitous fare,

Vnto the which he must hinselfe inure,

By exercise and rse of dyet spare.

And with the liquor of the waters pure,

Acquaint himselfe if he cannot forbeare.

And neuer on his greedy belly thinke,

From rising sunne vntill a low he sincke.

The twelth and last of all is memory,

Remembring well before he setteth out.

Each needfull thing that he must occupy,

And not to stand of any want in doubt,

Or leaue something behinde forgetfully:

When he hath walkt the fields and brokes about,

It were a griefe backe to retvrne againe,

For things forgot that should his sport maintaine.

Here then you see what kind of quallities, An Angler should indued be with all, Besides his skill and other properties,

To serue his turne, as to his lot doth fall:

But now what season for this exercise.

The fittest is and which doth serue lut small.

My Muse vouchsafe some little ayd to lend.

To bring this also to the wished end. 


\section{SEASON AND TIME NOT TO ANGLE.}

First, if the weather be to dry and hot,

And scalds with scorching heate the lowly plaine,

As if that youthfull Phaeton had got,

The guiding of his fathers Carre againe,

Or that it seem'd Apollo had forgot

His light foote steedes to rule with stedfast raine,

It is not good with any line or Hooke,

To Angle then in riuer, pond, or brooke.

Or when cold Borias with frosty beard,

Lookes out from vnderneath the lesser beare,

And makes the weary trauailer afeard,

To see the valleys couered euery where

With Ice and Snow, that late so greene appear'd,

The waters stand as if of steele they weare:

And hoary frosts doe hange on euery bough,

Where freshest leaues of summer late did grow.

So neither if Don Lolus lets goe,

His blustring windes out of the hollow deepe

Where he their strife and strugling to and fro

With triple forke doth still in order keepe,

They rushing forth cloe rage with tempests so,

As if they would the world togither sweepe,

And ruffling so with sturdy blasts they blow,

That tree and house sometimes they ouer throw.

Besides when shepheards and the swaines repare, Vnto the brookes with all their flockes of sheeps,

To wash their fleeces and to make them faire,

In euery poole and running water deepe,

The samour of the wooll doth so impaire,

The pleasant streames, and plunging that they keepe,

As if that Lethe-floud ran euerywhere,

Or bitter Doris intermingled were. 
Or when land flouds through long and sudden raine,

Discending from the hills and higher ground,

The sand and mud the cristall streames doe staine,

And make them rise abouc their wonted bound,

To ouer flow the fields and neighbour plaine,

The fruitfull soyle and Meadowes faire are drownd,

The husbandman doth leese his grasse and hay,

'The bankes their trees, and bridges borne away.

So when the leaues begin to fall apace,

And bough and braunch are naked to be seene,

While nature doth her former worke deface,

Vnclothing bush, and tree, of summers greene,

Whose scattered spoiles lye thicke in euery place,

As sands on shore or starres the poles betweene,

And top and bottome of the riuers fill,

To Angle then I also thinke it ill.

All windes are hurtfull if too hard they blow,

The worst of all is that out of the East,

Whose nature makes the Fish to biting slow,

And lets the pastime most of all the rest;

The next that comes from countries clad with Snow,

And Articque pole is not offensiue least,

The Southern winde is counted best of all,

Then, that which riseth where the sunne doth fall.

BEST TIMES AND SEASOIS TO AVGLE.

Bvt if the weather stedfast be and cleare,

Or ouercast with clouds, so it be dry,

And that no signe nor token there appeare,

Of threatning storm through all the empty skie,

But that the ayre is clame and voide of feare,

Of ruffling windes or raging tempests hie,

Or that with mikle and gentle gale they blow,

Then it is good vnto the lronke to goe. 
And when the flouds are fall'n and past away, And carried have the dregges into the deepe, And that the waters waxe more thin and gray, And leaue their bankes aboue them high and steepe, The milder streame of colour like to whay,

Within his bounds his wonted course doth keepe, And that the wind South or else by-IVest, To Angle then is time and seasons best.

When faire Aurora rising early shewes Her blushing face beyond the Easterne hils, And dyes the heauenly vault with purple rewes 'That far abroad the world with brightnes fils, The Meadowes greene are hoare with siluer dewes, That on the earth the sable night distills, And chanting birds with merry notes bewray, - The neere approaching of the chearefull day.

Then let him goe to Riuer, Brooke, or Lake, That loues the sport, where store of Fish abound, And through the pleasant fields his iourney make, Amid'st sweet Pastures, Meadowes fresh and sound, Where he may best his choice of pastime take, While swift Hyperion runnes his circle round; And as the place shall to his liking proue, There still remaine or further else remoue.

\section{TO KNOI EACH IISHES IIAUNT.}

Now that the Angler may the better know

Where he may finde each Fish he doth requirs, Since some delight in waters still and slow, And some doe loue the Mud and slimy mire; Some others where the streame doth swifter flow, Some stony ground, and grauell some desire, Here shall he learne how euery sort doe seeke, To haunt the Layre that doth his nature like. 
Carpe, Eele, and Tench, doe lone a muddie ground, Eeles vnder stones or hollow rootes doe lye;

The Tench among thicke weedes is soonest found, The fearfull Carpe into the deepe doth flie,

Bream, Chub and Pike, where clay and sand abound, Pike loues great pooles, and places full of frie:

The Chul delights in streame or shadie tree, And tender Breame in broadest lake to lee.

The Salmon swift the Riuers sweet doth like, Where largest streames into the Sea are led: The spotted Trout the smaller Brookes doth secke, And in the deepest hole there hides his head: The prickled Pearih in euery hollow creeke, Hard by the banke, and sandy shoare is fed. Pearch, Trout, and Salmon loue cleere waters all, Greene weedy rockes, and stony grauell small.

So doth the Bullicad, Goodsion, and the Luache, The most in shatiow lirookes delight to be, The Ruffe, the Daic, the Barbill, and the Ruach, Grauell and sand doe loue in lesse degree, But to the deepe and shade doe more approach, And ouerhead some couert loue to see,

Of spreading Poplar, Oake or Willuw greene, Where inderneath they lurke for beeing seene.

The mighty Luce great waters haunts alway, And in the stillest place thereof doth lye, saue when he raungeth foorth to secke his pring, And swift among the feerefull fish doth Hye, The dainty Humber loues the marley clay, And clecrest streames of champion countric heve, And in the chiefest poole:; thereof doth rest. Where he is soonest found and talien best. 
The Chauender amidst the waters fayre,

The swiftest streames doth most himselfe bestow,

The Shad and Trueat doe rather like the laire,

Of brackish waues, where it doth ebbe and flow,

And thither also doth the flocke repaire,

And flat vpon the bottom lyeth low,

The P'eele, the Mullet, and the Suant good

Doe like the same, and therein seeke their food.

Bvt here experience doth my skill exceed, Since diuers Countries diuers Riuers haue; And diuers Riuers change of waters breed, And change of waters sundry Fish doth craue, And sundry Fish in diuers places feede, As best doth like them in the liquid waue,

So that by vse and practise may be knowne,

More then by art or skill can well be showne.

So then it shall be needlesse to declare,

What sundry kindes there lie in secret store, And where they doe resort, and what they are,

That may be still discouered more and more:

Let him that list no paine or trauell spare

To seeke them out, as I haue done before,

And then it shall not discontent his minde,

New choice of place, and change of game to find.

THE BEST HOURES OF THE DAY TO ANGLE.

From first appearing of the rising Sunne,

Till nine of clocke low vnder water best

The Fish will bite, and then from nine to noone,

From noone to foure they doe refraine and rest,

From foure againe till Phobus swift hath runne,

His daily course, and setteth in the West:

But at the flie aloft they vse to bite,

All summer long from nine till it be night. 
Now least the Angler leaue his 'Tooles behinde, for lacke of heed or haste of his desire, And so inforced with vnwilling minde, Mifust leaue his game and backe again retire, such things to fetch as there he cannot finde To serue his turne when neede shall most require, Here shall he haue to helpe his memory, A. lesson short of etery wants supply.

light Rod to strike, long line to reach withall, Strong hooke to holde the fish he haps to hit, Spare Lines and Hookes, what euer chance doe fall, Baites quicke and dead to bring them to the bit, Fine Lead and Quils with Corks both great and smatl, Knife, File and thred, and little Basket fit, Plummets to sound the depth of clay and sand, With Pole and Net to bring them safe to land.

And now we are ariued at the last, In wisherl harboul where we meane to rest; And make an end of this our iourney past: Here then in quiet roade I thinke it best We strike our satiles and stedfast Anchor cast for now the Sumne low settech in the West, And yce Boat-Sawaines, a merry Carroll sing, To him that safely did ws hither bring. 


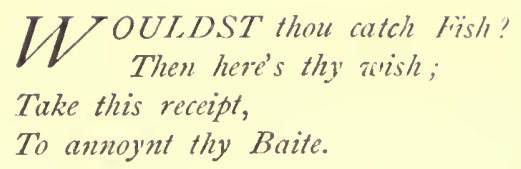

Thou that desir'st to fish with Line and Hooke, $\mathrm{Be}$ it in poole, in Riuer, or in Brooke, To blisse thy baite, and make the Fish to bite: Loe, here's a meanes, if thou canst hit it right, Take Gum of life, fine beat, and laid in soake, In Oyle, well drawne from that which kils the Oake. Fish where thou wilt, thou shalt haue sport thy fill, When twenty faile, thou shalt be sure to kill.

Probatum.

$$
\begin{aligned}
& \text { It's perfect and sond, } \\
& \text { If well inderstood; } \\
& \text { Else not to be tolde } \\
& \text { For Siluer or Golde. }
\end{aligned}
$$

B. R.

FINIS. 




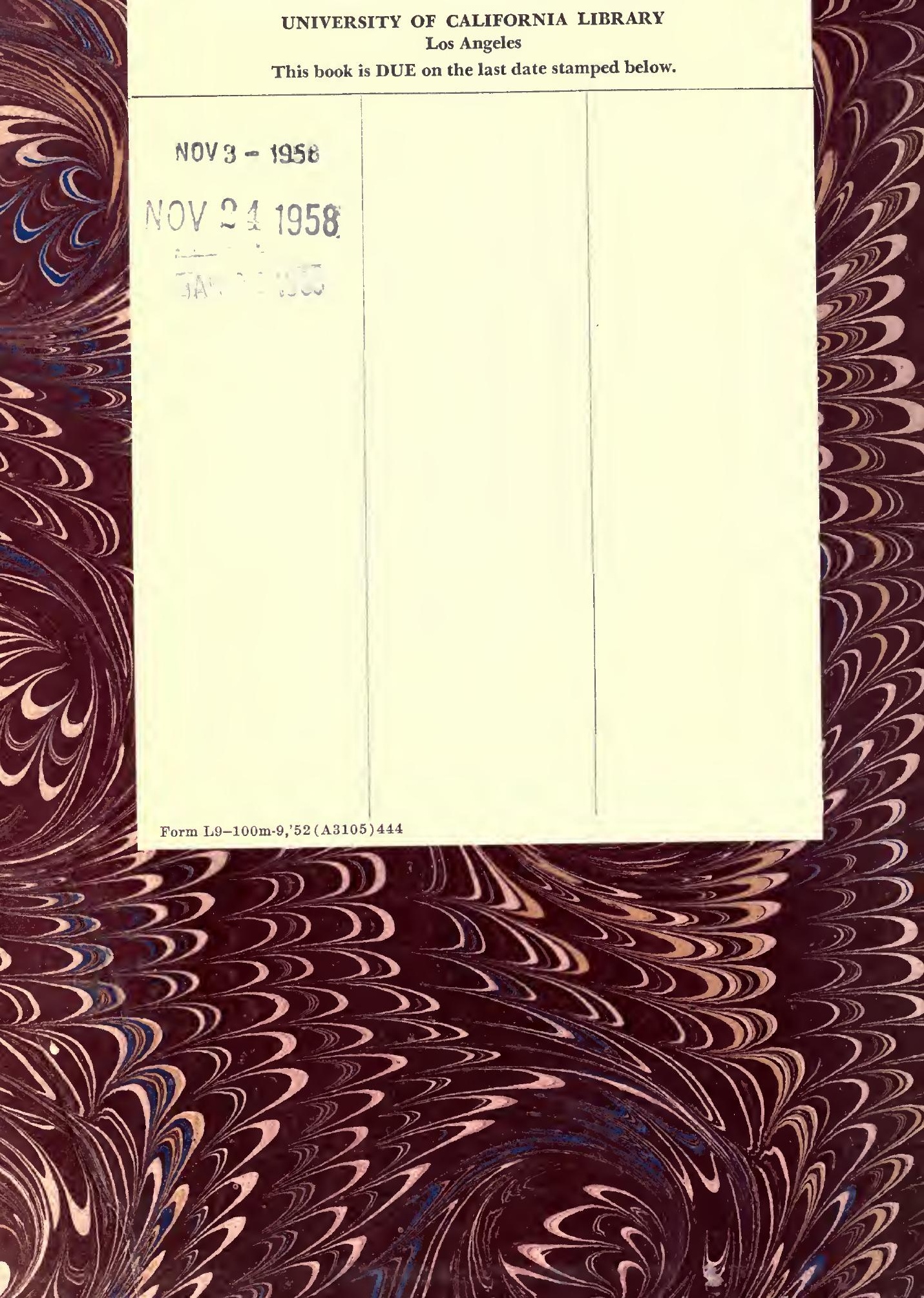




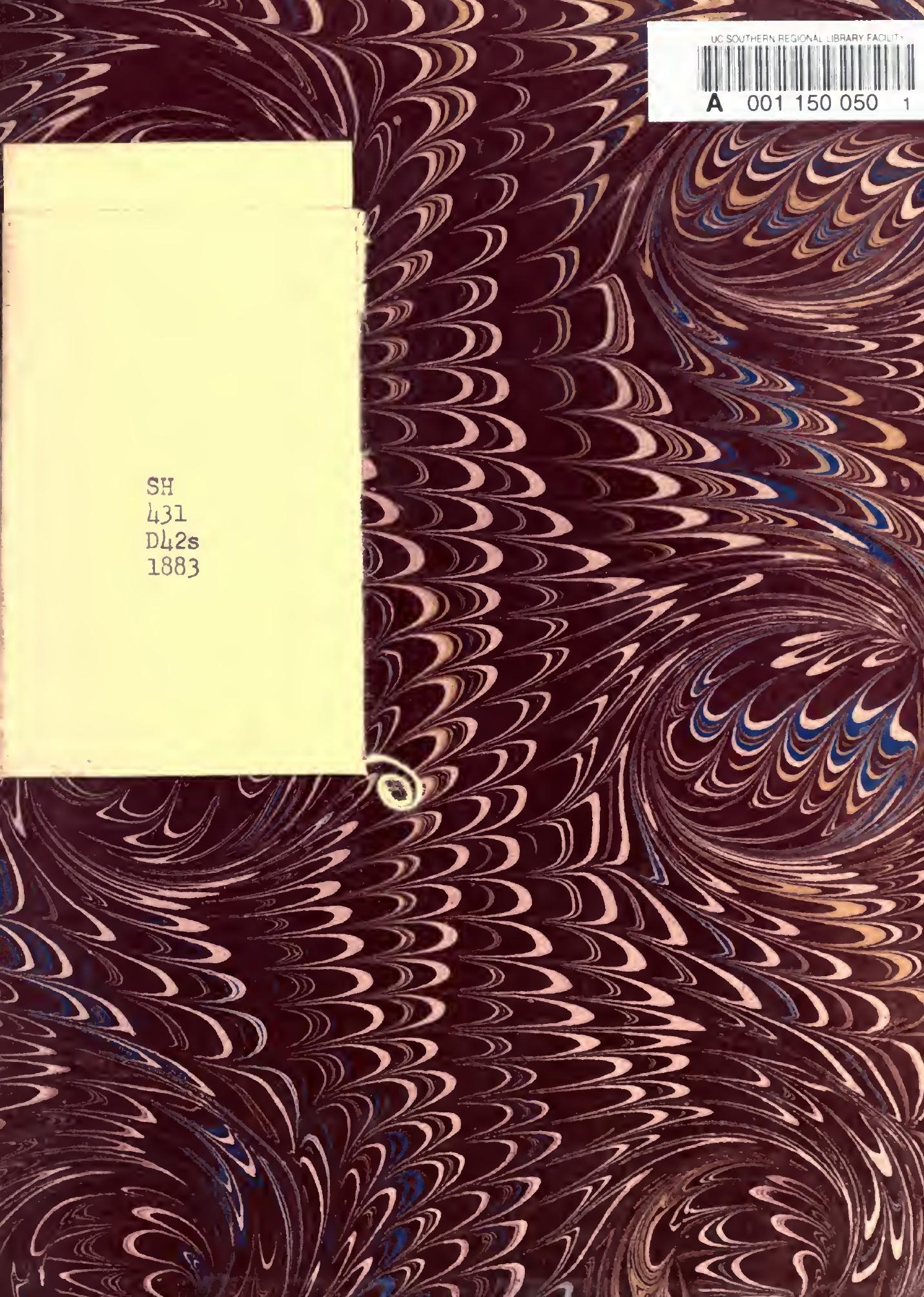




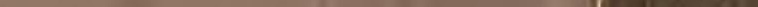

